\title{
Correlation of serum PTH level and fracture healing speed in elderly patients with hip fracture
}

\author{
Zhao-Nan Ban, Zheng-Jiang Li, Qi-Shan Gu, Jun Cheng, Qiang Huang and Shu-Xing Xing*
}

\begin{abstract}
Purpose: To access serum parathyroid hormone (PTH) level in elderly patients with hip fracture in relation to fracture healing outcomes.

Methods: This study included 90 elderly male patients with hip fracture and they were defined as the hip fracture group, and they were divided into healing effective group and delayed healing group by final fracture healing outcomes, 45 cases in each group; another 45 male patients older than 70 years without established osteoporosis and hip fracture were included as the control group. The levels of serum PTH level were examined in each group.

Results: Serum PTH level was significantly higher in healing effective group patients at the 7 days and 14 days after fracture than the delayed healing patients.

Conclusions: Our results show that serum PTH level may be an effective indicator of hip fracture delayed healing risk in the elderly.
\end{abstract}

Keywords: Elderly patients, Hip fracture, PTH, Fracture healing

\section{Introduction}

The main causes of senile osteoporosis include low levels of sex hormones and reduced synthesis of bone metabolism. Osteoporosis and frailty fractures are major public health issues with huge socio-economic costs [1-4]. It has been reported that changes in serum sex hormone levels increase the risk of fracture [5]. Also, lack of vitamin D results in an increase in parathyroid hormone (PTH) levels, leading to bone loss $[6,7]$. High bone turnover is associated with an increased risk of bone loss and also associated with an increased risk of fractures $[6,8,9]$ and independent of bone mineral density [6,10-12]. This study examined serum PTH levels in elderly male patients with hip fracture at different times and explored its relationship with fracture healing.

\footnotetext{
* Correspondence: xingshuxing@126.com

Department of Orthopedics, Chengdu Fifth People's Hospital, No.33 Ma Shi

Street, Wen jiang District, Chengdu 611130, Sichuan Province, People's

Republic of China
}

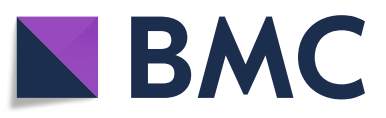

(c) The Author(s). 2019 Open Access This article is distributed under the terms of the Creative Commons Attribution 4.0 International License (http://creativecommons.org/licenses/by/4.0/), which permits unrestricted use, distribution, and

reproduction in any medium, provided you give appropriate credit to the original author(s) and the source, provide a link to the Creative Commons license, and indicate if changes were made. The Creative Commons Public Domain Dedication waiver (http://creativecommons.org/publicdomain/zero/1.0/) applies to the data made available in this article, unless otherwise stated.

\section{Material and methods \\ Clinical data of patients}

This is a retrospective analysis. This group with a total of 90 elderly male patients with hip fracture, aged 70 to 75 (72.6 \pm 7.5$)$ years (retired age with better physical condition) was divided into healing effective group and delayed healing group by final fracture healing outcomes, 45 cases in each group. Because of the large number of non-delayed union fracture cases, we randomly selected patients who met the inclusion criteria at the same time from the case series for matching. Another 45 male patients older than 70 years without established osteoporosis (no history of osteoporosis and no anti-osteoporosis treatment) and hip fracture were included as the control group, aged from 70 to 75 (71.8 \pm 6.9) years. Naturally, we let an uninformed nurse to extract the patient cases to avoid biases, and she did not know the patient's examination results and prognosis. Patients with renal diseases, hepatobiliary diseases, other bone diseases, and some drugs that effect to parathyroid hormone level were excluded. All blood samples were obtained in the morning before breakfast. The fracture which not reached the standard of complete healing of fracture within 4 
months was defined as bone delayed healing. The study was approved by the Ethics Review Committee of Chengdu Fifth People's Hospital, and all patients have signed the informed consent.

\section{Measurement method}

The venous plasma of patients in each group were collected at 1 day, 7 days, and 14 days after fracture. Serum levels of PTH were measured and averaged. The normal control group in the calm state by the same period of time for extraction of venous blood also takes the average calculation. Also, urea nitrogen (BUN), creatinine, aspartate transaminase (AST), alkaline phosphatase (ALP), albumin, calcium, phosphate, and total vitamin $\mathrm{D}$ were measured in the same sample.

\section{PTH levels}

Using enzyme-linked immunosorbent assay (ELISA), Human PTH ELISA kit were purchased from Aviva Systems Biology (OKEH00642), according to the kit instructions; samples were centrifuged to remove impurities and fibrinolytic block; and $100 \mathrm{uL}$ serum was taken for each sample. The ELISA experiment is operated in accordance with the specification process, and the color intensity is measured at $450 \mathrm{~nm}$.

\section{Statistical analysis}

The data were processed by Statistical Product and Service Solutions (SPSS) 21.0 software, and the serum $\mathrm{PTH}$ level was expressed as mean $\pm \mathrm{SD}$. One-way analysis of variance (ANOVA) and Student-Newman-Keuls (SNK) were used for comparison. A probability where $p<0.05$ was considered significant for all statistical comparisons.

\section{Results}

At the first day after fracture, serum PTH levels in patients with fracture have no significant difference compared with control group (Table 1); at 7 days after fracture, the level of serum PTH in patients from healing effective group was significantly higher than that of delayed healing group $(p=0.026)$ (Fig. 1$)$, but there was no significant difference between each fracture group; at 14 days after fracture, the level of serum PTH in patients from healing effective group was significantly higher than

Table 1 The changes of serum PTH levels at different times after facture

\begin{tabular}{llll}
\hline Group & 1 day & 7 days & 14 days \\
\hline Healing effective & $41.73 \pm 9.34$ & $50.29 \pm 11.62^{\#}$ & $67.92 \pm 12.17^{* \#}$ \\
Delayed healing & $42.61 \pm 10.26$ & $41.93 \pm 9.58$ & $41.02 \pm 9.42$ \\
Control & $41.95 \pm 8.57$ & $43.15 \pm 9.37$ & $43.05 \pm 10.20$ \\
\hline
\end{tabular}

$(n=45, \mathrm{pg} / \mathrm{mL}$, mean \pm SD)

Compared with the control group: ${ }^{*} p<0.05$

Compared with the control group and delayed healing group: ${ }^{*} s p<0.05$

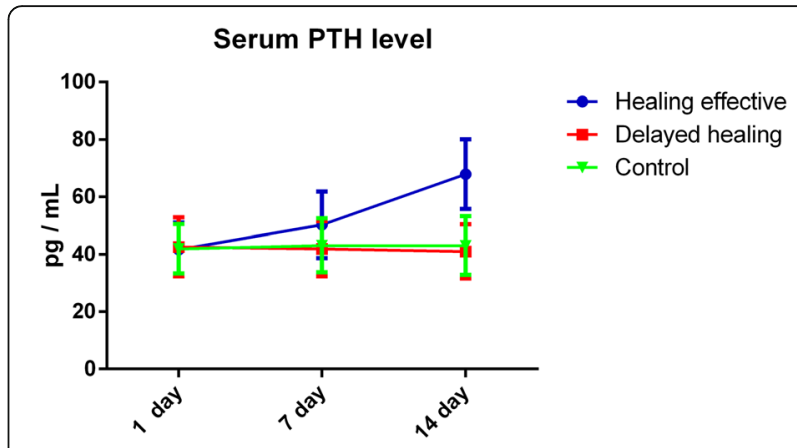

Fig. 1 PTH concentration in serum at the 1 day, 7 days, and 14 days after fracture in each group

that of delayed healing group ( $p=0.017$ ) (Fig. 1), and compared with the control group, the difference was significant $(p=0.021)$ (Fig. 1), but there was no significant difference between patients in delayed healing group and control group; serum PTH level in the healing effective group had increased in the above two time points; however, no significant difference was found in delayed healing group and the control group during the above two time points. The changes of serum PTH levels at different times after facture were presented in Table 1.

\section{Discussion}

Fracture healing process and different from that of other tissues and organs, not only for a long time, involved in many cells and in different healing stages have different cells and cytokines, the healing mechanism is more complicated. Androgen plays an important role in normal bone growth and regulation. Clinical studies have shown that androgen can stimulate the proliferation and differentiation of osteoblasts, increase the cytoplasm of the cells, and increase RNA and protein synthesis, and androgen can promote the secretion of growth hormone. Elderly fracture patients are often prone to Euthyroid Sick Syndrome (ESS); ESS showed that patients had abnormal thyroid hormone levels, but no thyroid disease performance. Elderly fracture patients with ESS present with low thyroid hormone levels and are associated with the severity of the disease. It is also reported that thyroid hormone monitoring is of great significance for the rehabilitation of patients undergoing orthopedic surgery [13, 14]. Parathyroid hormone secreted by the parathyroid gland consists of 84 amino acid residues. Its physiological function is to regulate calcium and phosphorus metabolism in the body. Therefore, high PTH regulates the production of adiponectin in the adipose tissue [15]. Intermittent low-dose recombinant human PTH promotes bone healing by upregulating the expression of mRNA and protein levels of the osteogenic gene Runx2 in the early stages of fracture healing [16]. Parathyroid hormone has been used to treat osteoporosis and reduce the risk of fracture. Animal 
studies on different fracture models have shown that the addition of PTH promotes fracture healing, increases the volume of the epiphysis and the mineral salt content of the fracture zone, and increases traction resistance [17, 18]. In human studies, PTH has a positive effect on fracture healing, and it seems to affect the role of bone growth factor. A prospective study of 32 patients with nonunion fracture healing from Kastirr et al. found that 95\% nonunion patients treated with PTH eventually healed after treatment [19]. We found that PTH levels in healing effective group were higher than those in delayed healing group at the 7 and 14 days after fracture, indicating the role of PTH in fracture healing. PTH is the first bone anabolic drug approved for the treatment of osteoporosis, preventing the delay of fracture healing due to aging [20, 21]. In some high-risk groups, such as the elderly, malnutrition, and postmenopausal women, PTH has better prospects for fracture treatment.

\section{Conclusion}

Serum PTH level was significantly higher in healing effective group patients at the 7 days and 14 days after fracture than the delayed healing patients. Our results show that serum PTH level may be an effective indicator of hip fracture delayed healing risk in the elderly.

\section{Abbreviations}

ALP: Alkaline phosphatase; ANOVA: One-way analysis of variance; AST: Aspartate transaminase; BUN: Urea nitrogen; ELISA: Enzyme-linked immunosorbent assay; PTH: Parathyroid hormone; SNK: Student-NewmanKeuls

\section{Acknowledgements}

All authors gratefully acknowledge the support of the subjects who participated in the present study.

\section{Authors' contributions}

All the authors conceived the idea and initiated the project. ZNB collected the data. ZJL and QSG performed the analysis. All authors participated in the interpretation of the results and critically reviewed the manuscript. All authors read and approved the final manuscript.

\section{Funding}

Not applicable

\section{Availability of data and materials}

Not applicable

\section{Ethics approval and consent to participate}

This study was approved by the Ethics Committee of the Hospital. The aim and the method of the study were explained to the participants, and they were also informed by a standard written information form. Written informed consent was obtained from the participants prior to inclusion in the study to ensure that the participation was voluntary (Declaration of Helsinki 2013).

\section{Consent for publication}

All consents to publish from the participants who took part in this study were obtained.

\section{Competing interests}

The authors declare that they have no competing interests.
Received: 10 July 2019 Accepted: 14 October 2019

Published online: 12 November 2019

\section{References}

1. Looker AC, Orwoll ES, Johnston CJ, Lindsay RL, Wahner HW, Dunn WL, Calvo MS, Harris TB, Heyse SP. Prevalence of low femoral bone density in older U.S. adults from NHANES III. J Bone Miner Res. 1997;12(11): 1761-8.

2. Court-Brown CM, Caesar B. Epidemiology of adult fractures: a review. INJURY. 2006;37(8):691-7.

3. Burge R, Dawson-Hughes B, Solomon DH, Wong JB, King A, Tosteson A. Incidence and economic burden of osteoporosis-related fractures in the United States, 2005-2025. J Bone Miner Res. 2007;22(3):465-75.

4. Cummings SR, Melton LJ. Epidemiology and outcomes of osteoporotic fractures. LANCET. 2002:359(9319):1761-7.

5. Goderie-Plomp HW, van der Klift M, de Ronde W, Hofman A, de Jong FH, Pols HA. Endogenous sex hormones, sex hormone-binding globulin, and the risk of incident vertebral fractures in elderly men and women: the Rotterdam study. J Clin Endocrinol Metab. 2004;89(7):3261-9.

6. Garnero P, Sornay-Rendu E, Chapuy MC, Delmas PD. Increased bone turnover in late postmenopausal women is a major determinant of osteoporosis. J Bone Miner Res. 1996;11(3):337-49.

7. Sakuma M, Endo N, Oinuma T, Hayami T, Endo E, Yazawa T, Watanabe K, Watanabe S. Vitamin D and intact PTH status in patients with hip fracture. Osteoporos Int. 2006;17(11):1608-14.

8. Szulc P, Delmas PD. Biochemical markers of bone turnover: potential use in the investigation and management of postmenopausal osteoporosis. Osteoporos Int. 2008;19(12):1683-704.

9. Garnero P, Sornay-Rendu E, Duboeuf F, Delmas PD. Markers of bone turnover predict postmenopausal forearm bone loss over 4 years: the OFELY study. J Bone Miner Res. 1999;14(9):1614-21.

10. Szulc P, Garnero P, Marchand F, Duboeuf F, Delmas PD. Biochemical markers of bone formation reflect endosteal bone loss in elderly men-MINOS study. BONE. 2005;36(1):13-21

11. Sornay-Rendu E, Munoz F, Garnero P, Duboeuf F, Delmas PD. Identification of osteopenic women at high risk of fracture: the OFELY study. J Bone Miner Res. 2005:20(10):1813-9.

12. Bauer DC, Garnero P, Harrison SL, Cauley JA, Eastell R, Ensrud KE, Orwoll E. Biochemical markers of bone turnover, hip bone loss, and fracture in older men: the MrOS study. J Bone Miner Res. 2009;24(12):2032-8.

13. Aprile I, Romitelli F, Piazzini DB, Padua L, Lancellotti S, Maggi L, Zuppi C, Bertolini C, Di Stasio E. Effects of rehabilitation treatment on thyroid function. Clin Endocrinol. 2009;70(4):644-9.

14. Erkol IE, Carli AB, Canak S, Aksu O, Koroglu BK, Savas S. Effects of hyperthyroidism on hand grip strength and function. J Rehabil Res Dev. 2015:52(6):663-8.

15. Fisher L, Srikusalanukul W, Fisher A, Smith P. Liver function parameters in hip fracture patients: relations to age, adipokines, comorbidities and outcomes. Int J Med Sci. 2015;12(2):100-15.

16. Tsuchie H, Miyakoshi N, Kasukawa Y, Aonuma H, Shimada Y. Intermittent administration of human parathyroid hormone before osteosynthesis stimulates cancellous bone union in ovariectomized rats. Tohoku J Exp Med. 2013;229(1):19-28.

17. Pietrogrande $L$, Raimondo $E$. Teriparatide in the treatment of non-unions: scientific and clinical evidences. INJURY. 2013:44(Suppl 1):S54-7.

18. Barvencik F. Medication and bone metabolism: clinical importance for fracture treatment. UNFALLCHIRURG. 2015:118(12):1017-24.

19. Kastirr I, Reichardt M, Andresen R, Radmer S, Schroder G, Westphal T, Mittlmeier T, Schober HC. Therapy of aseptic nonunions with parathyroid hormone. Eur J Orthop Surg Traumatol. 2019;29(1):169-73.

20. Lou S, LV H, Li Z, Tang P, Wang Y. Parathyroid hormone analogues for fracture healing: protocol for a systematic review and meta-analysis of randomised controlled trials. BMJ Open. 2018;8(1):e19291.

21. Ellegaard M, Jorgensen NR, Schwarz P. Parathyroid hormone and bone healing. Calcif Tissue Int. 2010;87(1):1-13.

\section{Publisher's Note}

Springer Nature remains neutral with regard to jurisdictional claims in published maps and institutional affiliations. 